Avrupa Bilim ve Teknoloji Dergisi

Özel Sayl, S. 211-214, Ağustos 2020

(C) Telif hakkı EJOSAT'a aittir

Araștırma Makalesi
European Journal of Science and Technology

Special Issue, pp. 211-214, August 2020

Copyright (C) 2020 EJOSAT

Research Article

\title{
Lame Diferansiyel Denkleminin Komütativite Koşulları
}

\author{
Mehmet Emir Köksal \\ Ondokuz Mayıs University, Department of Mathematics, 55139, Samsun, Turkey (ORCID: 0000-0001-7049-3398)
}

(Bu yayın 26-27 Haziran 2020 tarihinde HORA-2020 kongresinde sözlü olarak sunulmuştur.)

(DOI: 10.31590/ejosat.779704)

ATIF/REFERENCE: Köksal, M.E. (2020). Commutativity Conditions of Lame's Differential Equation. Avrupa Bilim ve Teknoloji Dergisi, (Special Issue), 211-214.

\section{$\ddot{O} \mathbf{z}$}

Çoğu mühendislik sistemlerinin gerçekleştirilmesi, daha basit sistemlerin ardışık bağlantıları ile yapılmaktadır. Bu durum elektrik ve elektronik sistemlerinin tasarımında çok önemlidir. Her ne kadar bu alt sistemlerin bağlantı sırası, kullanılan özel tasarım yöntemlerine, mühendislik tecrübesine, alışlagelmiş sentez yöntemlerine bağlı olmakla beraber, hassasiyet, kararlılık, doğrusallık, gürültüden etkilenme ve dayanıklılık hususları göz önüne alındığında toplam sistemin ana fonksiyonunu değiştirmeden alt sistemlerin bağlantı sırasının değiştirilmesi (komütativite) pozitif sonuçlara yol açabilmektedir. Bu nedenle pratik uygulamalar açısından komütativite çok önemlidir. Bu çalışmada, Lame diferansiyel denkleminin bir türünün komütativite koşulları incelenmiştir. İkinci dereceden doğrusal zamanla değişen sürekli-zaman sistemlerinin komütativitesi için teorik sonuçlar ışığında Lame'nin diferansiyel denklemi ile modellenen sistemin denklemin parametrelerine bağlı olarak komütatif çiftleri olduğu kanıtlanmıştır. Lame diferansiyel denklemi ile modellenen sistemin komütatif eşleniği oluşturulmuştur. Teorik sonuçları desteklemek için açıklayıcı bir örnek ele alınmıştır. Örnek’te MATLAB 2019b'nin Simulink araç kutusu kullanılmışır. Sabit adım uzunluğuna sahip çözücü olarak Ode45 kullanılmıştır. Sayısal sonuçlar sunulmuştur. $x \in[0,120]$ için hesaplanan cevapların özdeş olduğu, bunun da sıfır başlangıç koşulları altında komütativite sonuçlarının geçerliliğini kanıtladığı görülmüştür. Rasgele seçilen başlangıç koşulları ile komütativitenin geçerli olup olmadığı da test edilmiştir. Komütativitenin uygun şekilde seçilmeyen, keyfi olarak seçilen başlangıç koşulları için bozulduğu gözlenmiştir. Lame diferansiyel denklemi ile modellenen sistemlerin sıfır olmayan başlangıç koşulları ile komütativite teorisi, (Koksal, 2019b) genel formülleri kullanılarak ilerili çalışmalarda incelenebilir.

Anahtar Kelimeler: Komütativite, Analog Sistemler, Lame Diferansiyel Denklemi, Zamanla Değişen Sistemler.

\section{Commutativity Conditions of Lame's Differential Equation}

\begin{abstract}
The realization of many engineering systems consists of cascade connection of systems of simple orders, which is very important in design of electrical and electronic systems. Although the order of connection of the systems mainly depends on the special design approach, engineering ingenuity, traditional synthetic methods, when the sensitivity, stability, linearity, noise disturbance, robustness effects are considered the change of the order of connection without changing the main function of the total systems (commutativity) may lead positive results. Therefore, the commutativity is very important from the practical point of view. In this study, commutativity conditions of one type of Lame's differential equations are considered. In the sense of theoretical results for the commutativity of second-order continuous-time linear time-varying systems, it is proved that the system modeled by a Lame's differential equation has commutative pairs depending on the parameters of the equation. Commutative conjugate of the system modeled by a Lame's differential equation is constructed. To support the theoretical results, an illustrative example is considered for application. For the illustration, Simulink toolbox of MATLAB 2019b is used. Ode5 (Dormant-Prince) is used as the solver with a fixed step-length. Numerical results are presented. It is observed that the responses computed for $x \in[0,120]$ are identical, which proves the validity of the commutativity results under zero initial conditions. The validity of commutativity with arbitrary initial conditions is also tested. It is observed that the commutativity is spoiled for arbitrarily chosen initial conditions which are not chosen appropriately. Theory of commutativity of the system modeled by Lame's differential equation with non-zero initial conditions can be conducted in future work using the general formulas in (Koksal, 2019b).
\end{abstract}

Keywords: Commutativity, Analog System, Lame's Differential Equations, Time-varying Systems. 


\section{Introduction}

The commutativity is a very important subject concerning engineers and mathematicians. Especially, it places an important role to improve different system performances in system and control design as a main branch of electrical and electronics engineering. For example, commutative subsystems are used in cascade connected and feedback structures to design higher order composite systems for achieving several beneficial properties such as controllability, sensitivity, robustness, and design flexibility.

Firstly, this subject was studied in the literature by E. Marshall in 1982 (Marshall, 1977) for the first-order linear time-varying differential systems. After that, commutativity conditions of second-order (Koksal, 1982), third-order (Koksal, 1985a), and fourthorder (Koksal, 1985b), systems were obtained by M. Koksal in 1982, 1985a and 1985b respectively. After a long time, commutativity of fifth-order systems (Koksal et al., 2011) was studied by M. Koksal and M.E. Koksal in 2011.

Although most of the famous second-order linear time-varying differential systems were subjected from the commutativity point of view in (Koksal, 2018a, 2018b), Lame's differential equation (Zwillinger, 1997) is not among them. So the purpose of this presentation is to study the commutativity conditions of Lame differential equation; namely

$$
\ddot{y}+\frac{1}{2}\left(\frac{1}{x-c}+\frac{1}{x-d}+\frac{1}{x-e}\right) \dot{y}+\frac{a+b x}{4(x-c)(x-d)(x-e)} y=0
$$

Here $a, b, c, d, e$, are constants. Note that $\ddot{y}_{A}(t)=\frac{d^{2}}{d t^{2}} y_{A}(t), \dot{y}_{A}(t)=\frac{d}{d t} y_{A}(t)$, and the initial conditions are assumed to be zero.

\section{Commutativity Conditions of Second-order Systems}

We assume that $A$ be linear time-varying second-order differential system described by the following second-order differential equations:

$$
a_{2}(t) \ddot{y}_{A}(t)+a_{1}(t) \dot{y}_{A}(t)+a_{0}(t) y_{A}(t)=x_{A}(t) ; t \geq 0 .
$$

Here, $x_{A}(t)$ is the independent excitation and $y_{A}(t)$ is the resulting response. For the unique solution of Eq. (2) for $t \geq t_{0}$, it is sufficient that the excitation and the time-varying coefficients $a_{2}(t), a_{1}(t), a_{0}(t)$ be piece-wise continuous functions of time with $a_{2}(t) \not \equiv 0$.

The system modeled by Eq. (2) has a commutative pair if and only if the coefficients of the system satisfy the following equation:

$$
-a_{2}^{0.5} \frac{d}{d t}\left[a_{0}-\frac{1}{16 a_{2}}\left(4 a_{1}^{2}+3 \dot{a}_{2}^{2}-8 a_{1} \dot{a}_{2}+8 \dot{a}_{1} a_{2}-4 a_{2} \ddot{a}_{2}\right)\right] k=0,
$$

where $k$ is a constant. In (Koksal, 1982), it is proved that commutative pairs of (2) are obtained by

$$
\left[\begin{array}{l}
b_{2} \\
b_{1} \\
b_{0}
\end{array}\right]=\left[\begin{array}{ccc}
a_{2} & 0 & 0 \\
a_{1} & a_{2}^{0.5} & 0 \\
a_{0} & a_{2}^{-0.5}\left(2 a_{1}-\dot{a}_{2}\right) / 4 & 1
\end{array}\right]\left[\begin{array}{l}
k_{2} \\
k_{1} \\
k_{0}
\end{array}\right],
$$

where $k_{2}, k_{1}=$ same $k$ in Eq. (3), $k_{0}$ are some constants. Then any commutative pair $B$ of $A$ is described by

$$
b_{2}(t) \ddot{y}_{B}(t)+b_{1}(t) \dot{y}_{B}(t)+b_{0}(t) y_{B}(t)=x_{B}(t) .
$$

\section{Commutativity of Lame Differential Equation}

Using the above theoretical bases, we investigate the commutativity conditions for Lame differential equations given in (1). Note that if $k=k_{1}=0$ in Eqs. (3) and (4), Eq. (3) is automatically satisfied for all time-varying linear second order systems $A$; the commutative pairs $B$ of $A$ are then obtainable from $A$ with constant feedback and constant feedforward gains (Koksal, 2019a). This special case is out of scope of this presentation.

The coefficients of Heine differential equation in (1) are

$$
a_{0}(x)=\frac{a+b x}{4(x-c)(x-d)(x-e)}, a_{1}(x)=\frac{1}{2}\left(\frac{1}{x-c}+\frac{1}{x-d}+\frac{1}{x-e}\right), a_{2}(x)=1 .
$$

Because of the fact that derivative of $a_{2}(x)$ is equal to zero, the commutativity condition in Eq. (3) yields that the expression $4 a_{0}-$ $a_{1}^{2}-2 \dot{a}_{1}$ must be a constant (excluding the mentioned special case $k=k_{1}=0$ ) say $C$. Using the formulas of $a_{0}(x), a_{1}(x)$ and $\dot{a}_{1}(x)=-\frac{1}{2}\left[\frac{1}{(x-c)^{2}}+\frac{1}{(x-d)^{2}}+\frac{1}{(x-e)^{2}}\right]$, we obtain 


$$
\frac{4(a+b x)}{(x-c)(x-d)(x-e)}+3\left[\frac{1}{(x-c)^{2}}+\frac{1}{(x-d)^{2}}+\frac{1}{(x-e)^{2}}\right]-\left[\frac{2}{(x-c)(x-d)}+\frac{2}{(x-c)(x-e)}+\frac{2}{(x-d)(x-e)}\right]=C .
$$

For finding the parameter values satisfying the above equation, we equalize the denominators at the left side of the equation. Then, we multiply both sides of the equation by $(x-c)^{2}(x-d)^{2}(x-e)^{2}$ and obtain the following expression:

$$
\begin{gathered}
4(a+b x)(x-c)(x-d)(x-e)-2(x-c)(x-d)(x-e)^{2}-2(x-c)(x-d)^{2}(x-e) \\
-2(x-c)^{2}(x-d)(x-e)+3(x-c)^{2}(x-d)^{2}+3(x-c)^{2}(x-e)^{2}+3(x-d)^{2}(x-e)^{2}=C(x-c)^{2}(x-d)^{2}(x-e)^{2} .
\end{gathered}
$$

So, we obtain a fourth-order and six-order polynomials at the left and right sides of the equation respectively. Because of the fact that the order of the polynomial at the right side of the above equation is greater than fourth-order, $C$ should be equal to zero. Then, we obtain

$$
b=-\frac{3}{4}
$$

by equalizing the coefficients of $x^{4}$. By equalizing the coefficients of $x^{3}$, we find

$$
a=\frac{1}{4}(e+d+c)
$$

Using $b$ and the formula of $a$, we obtain the following equations by equalizing the coefficients of $x^{2}, x^{1}$ and $x^{0}$ in Eq. (8), respectively:

$$
\left\{\begin{array}{l}
c^{2}+d^{2}+e^{2}=c d+c e+d e \\
6 c d e=c d^{2}+c^{2} d+c e^{2}+c^{2} e+d^{2} e+e d^{2} \\
c^{2} d^{2}+c^{2} e^{2}+e^{2} d^{2}=c d e(c+d+e)
\end{array}\right.
$$

Manipulations of the above system of nonlinear algebraic equations, we get

$$
c=d=e=\alpha,
$$

where $\alpha$ is an arbitrary constant number. With these results, the parameter values can be summarized as

$$
b=-\frac{3}{4}, a=\frac{3}{4} \alpha, \quad c=d=e=\alpha .
$$

\section{Example}

To demonstrate the validity of the results, consider the Lame's differential equation with parameters chosen according to the formulas in Eq. (13) with $\alpha=-1$; namely $a=-0.75, b=-0.75, c=d=e=-1$. Then, the differential system becomes explicitly

$$
A: \ddot{y}_{A}+\frac{3}{2(x+1)} \dot{y}_{A}-\frac{3}{16(x+1)^{2}} y_{A}=U_{A}
$$

The constant $k_{2}, k_{1}, k_{0}$ in Eq. (4) are chosen as $k_{2}=1, k_{1}=3, k_{0}=2$ yielding the commutative subsystem

$$
B: \ddot{y}_{B}+\frac{6 x+9}{2(x+1)} \dot{y}_{B}+\frac{32 x^{2}+100 x+65}{16(x+1)^{2}} y_{B}=U_{B} .
$$

The cascade connections $A B$ and $B A$ are formed by the Simulink toolbox of MATLAB $2019 \mathrm{~b}$ and excited by a composite input which is the sum of a sine wave with amplitude 1 and frequency $1 \mathrm{rad} / \mathrm{s}$, a step of -0.4 at $x=0$, and a pulse train of amplitude 1 , period 20, pulse-width $40 \%$. The input and the responses of both connections are shown in Fig. 1. It is observed that the responses computed for $x \in[0,120]$ are identical, which proves the validity of the commutativity results under zero initial conditions. Ode5 (DormantPrince) is used as the solver with a fixed step-length of 0.01 . 


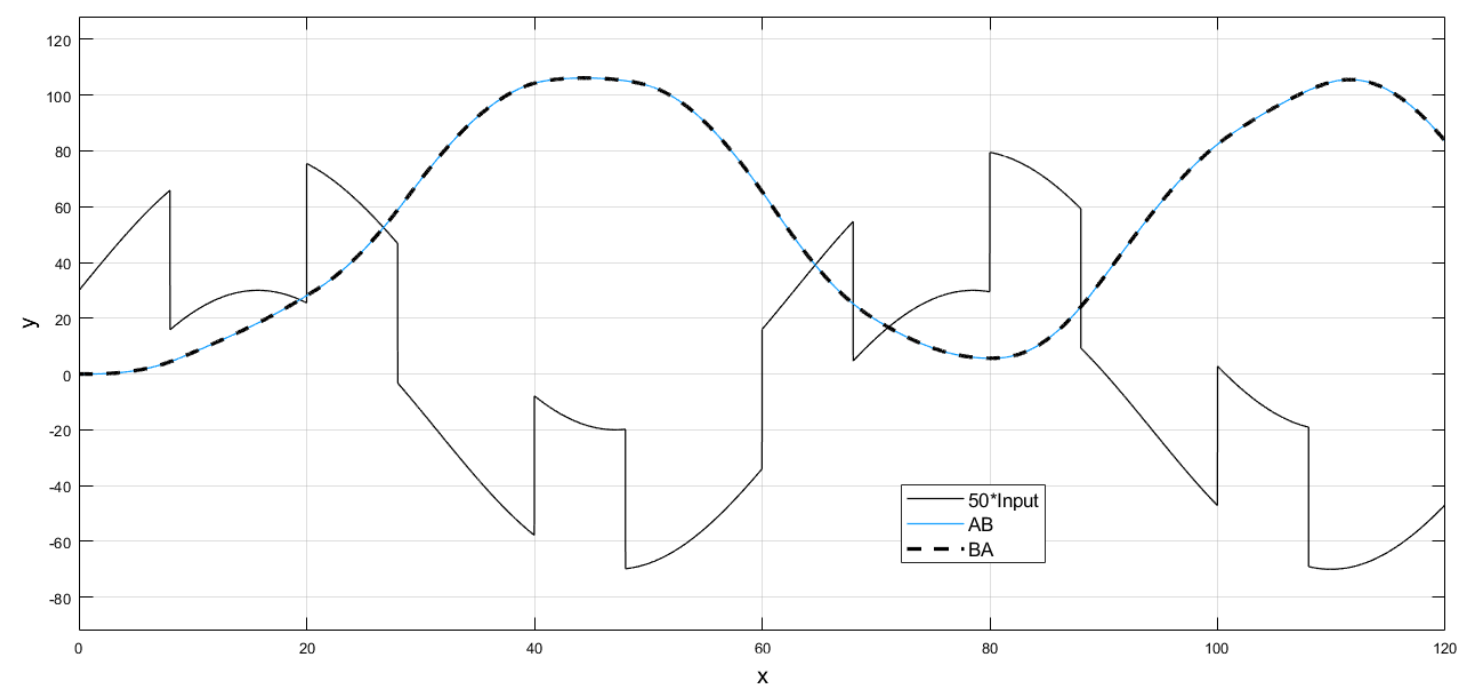

Figure 1. The input and output functions with zero initial conditions.

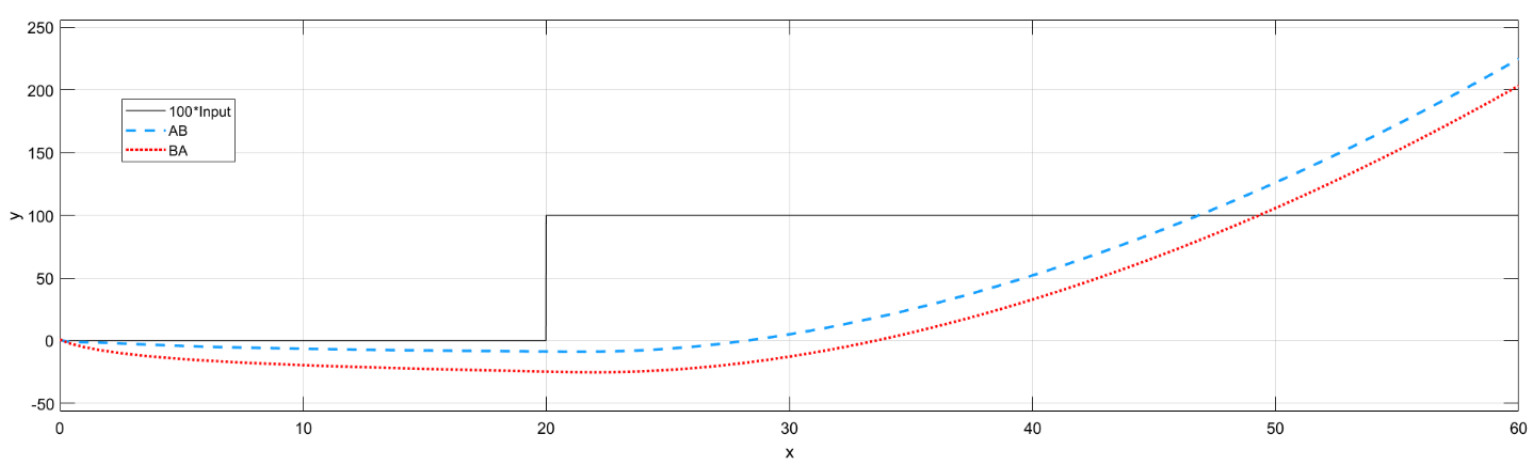

Figure 2. The input and output functions with non-zero initial conditions.

To test the validity of commutativity with arbitrary initial conditions, $y_{A}(0)=y_{B}(0)=-1, \dot{y}_{A}(0)=\dot{y}_{B}(0)=-10$ are used with a step input starting at $x=20$. As shown in Fig. 2, the output responses of $A B$ and $B A$ are not identical, that is the commutativity is spoiled. This is because the initial conditions are not chosen appropriately. Theory of commutativity of Lame's differential system with non-zero initial conditions can be conducted using the general formulas in (Koksal, 2019b).

\section{Acknowledgment}

This work was supported by the Scientific and Technological Research Council of Turkey under the project no. 115E952.

\section{References}

Koksal, M. (1982). Commutativity of second order time-varying systems. International Journal of Control. 3, 541-44.

Koksal, M. (1985a). A survey on the commutativity of time-varying systems. METU, Technical Report. no: GEEE CAS-85/1.

Koksal, M. (1985b). Commutativity of $4^{\text {th }}$ order systems and Euler systems. Presented in National Congress of Electrical Engineers. Paper no: BI-6, Adana, Turkey.

Koksal, M. and Koksal, M. E. (2011). Commutativity of linear time-varying differential systems with non-zero initial conditions: A review and some new extensions. Mathematical Problems in Engineering. 2011, 1-25.

Koksal, M. E. (2018a). Commutativity and commutative pairs of some well-known differential equations. Communications in Mathematics and Applications. 9 (4), 689-703.

Koksal, M. E. (2018b). Commutativity conditions of some time-varying systems. International Conference on Mathematics: "An Istanbul Meeting for World Mathematicians". 3-6 Jul 2018, Istanbul, Turkey, pp. 109-117.

Koksal, M. E. (2019a). Commutativity of systems with their feedback conjugates. Transactions of the Institute of Measurement and Control. 41 (3), 696-700.

Koksal, M. E. (2019b). Explicit commutativity conditions for second order linear time-varying systems with non-zero initial conditions. Archives of Control Sciences. 29 (3), 413-432.

Marshall, J. E. (1977). Commutativity of time varying systems. Electro Letters. 18, 539-40.

Zwillinger, D. (1997). Handbook of Differential Equations. 3rd ed. Boston, MA: Academic Press, p. 127. 